\title{
The true panel of cystic fibrosis mutations in the Sicilian population
}

\author{
Sandrine Chamayou ${ }^{1 *} \mathbb{D}$, Maria Sicali ${ }^{1}$, Debora Lombardo ${ }^{1}$, Elena Maglia ${ }^{1}$, Annalisa Liprino ${ }^{1}$, Clementina Cardea $^{1}$, \\ Michele Fichera ${ }^{2}$, Ermanno Venti ${ }^{1}$ and Antonino Guglielmino ${ }^{1}$
}

\begin{abstract}
Background: The aim was to establish the true risk of having an affected child with Cystic Fibrosis (CF) in the Sicilian infertile population.

Methods: A longitudinal CFTR screening of 1279 Sicilian infertile patients for all CFTR mutations sequencing the entire gene by Next Generation Sequencing (NGS) was performed from patient's blood.

Results: One patient out of 16 was a carrier of a CFTR mutation. Twenty-four mutations were found. Theoretically one couple out of 256 was at risk of CF transmission.

Conclusions: The risk of CF transmission is unexpectedly high in Sicily and with a high heterogeneity. Sequencing an entire and long gene such as CFTR makes accessible the true panel of mutations in a specific population and helps better to understand the true risk of having an affected child.
\end{abstract}

Keywords: CFTR, Cystic fibrosis, Next generation sequencing, Screening, Sicily

\section{Capsule}

Screening all mutations by sequencing the entire gene of CFTR with NGS makes accessible the real panel of mutations in a specific population and helps better to establish the true risk of having an affected child. In Sicily, 1 infertile patient out of 16 was a carrier of a Cystic Fibrosis mutation and 24 mutations were detected.

\section{Background}

Cystic fibrosis (CF) is the most common autosomal recessive disease in the Caucasian population as one person in 25 is a carrier [1] and the incidence is 1 in 3500 live births [2]. The cystic fibrosis transmembrane conductance regulator (CFTR) gene [3, 4] is responsible for the disease. The gene is located in position 7q31.2, is compound of 27 exons and encodes for the cyclic adenosine monophosphate dependent chloride channel located in the apical membrane of secretory epithelial cells $[5,6]$. The transmembrane protein inactivity due to CFTR gene mutation induces hyper-

* Correspondence: s.chamayou@yahoo.fr

${ }^{1}$ Unità di Medicina della Riproduzione - Centro HERA, via Barriera del Bosco

n. 51/53, 95030 Catania, Sant'Agata Li Battiati, Italy

Full list of author information is available at the end of the article viscosity of epithelial secretions. The first Cystic Fibrosis Mutation Database recorded 2067 genomic variants [7]. On the 11th March of 2019, the number of CF causing mutations has been recalculated as 383; most of the genomic variants have been removed because found in only one patient in the world [8]. The clinical symptomatology of the disease is widely variable from a mild clinical expressivity with atypical pancreatitis and bronchiectasis to severe health consequences including chronic pulmonary obstruction, infections, exocrine pancreatic insufficiency and death [9].

In male patients, the absence or severely reduced activity of CFTR protein can lead to excessive viscosity of the epididymal fluid associated with infertility [10-12] and/or congenital bilateral absence of vas deferens (CBAVD) $[13,14]$. Common CFTR mutations such as F508del were found to be involved in the pathogenesis of CBAVD when associated with the variant at the intron 8 poly TG-poly $\mathrm{T}$ abbreviated as 'TG12;5 T' [15-17].

In 2009, the latest practice European guidelines for molecular genetic diagnosis of CF and CFTR-related disorders were published [18]. At that time, the available methods for mutation detection were based on either the direct gene analysis of known mutations (heteroduplex analysis, restriction enzyme analysis, reverse dot 
blot hybridization, amplification refractory mutation system, oligonucleotide ligation assay,...) or on the detection of unknown mutations (DGGE, DHPLC, SSCP, gene sequencing, quantitative fluorescent multiplex PCR, MLPA). In Assisted Reproductive Techniques, the approach of CFTR screening is to test the patient(s) for a limited number of known mutations with commercial kits. Nevertheless, nearly the $25 \%$ of CF mutations could remain untested and so the resulted percentage of being a carrier would be undervalued [19]. Moreover, the percentage of undetected mutations increases from Northern to Southern Europe [18]. In Italy, twelve mutations are responsible for the main $\mathrm{CF}$ genotypes with a frequency from 63 to $85 \%$ according to the Region [20].

Recent technological advances such as Next Generation Sequencing (NGS) enlarged the spectrum of detectable mutations [21, 22]. We present the first report of longitudinal screening for CF on Sicilian infertile population by sequencing the entire CFTR gene by NGS.

\section{Methods}

\section{Patients undergoing CF screening}

From July 2014 to June 2019, 1155 couples living in Sicily and coming for infertility counselling were screened for the risk of CF transmission. The entire gene was sequenced by NGS from blood sample of one member of the couple. If the first member resulted as a carrier of CFTR mutation(s) or carrier of the genomic variant TG12; $5 \mathrm{~T}$, the CFTR mutations screening was extended to the second member. In total, 1279 Caucasian patients (1055 males and 224 females) were screened. If the couple resulted to be at risk for CF transmission, the principles and protocols of prenatal diagnosis and preimplantation genetic testing (PGT) for CF were explained.

\section{CF screening from blood}

The present CF screening protocol was previously validated by an international network for CFTR gene mutations detection using NGS [21, 23]. It was established that the test had $99.7 \%$ of accuracy and $93.8 \%$ of specificity. The protocol of CF screening from blood has been previously published [23] and is summarized here: genomic DNA was extracted from peripheral blood using the standard protocol of the High Pure PCR Template Preparation Kit (Roche Diagnostics). $5 \mathrm{ng}$ of genomic DNA from each sample was used to prepare amplicon libraries according to the Ion Ampliseq CFTR Panel (Life Technologies-Thermo Fisher, Carlsbad, USA). All libraries were barcoded, mixed and clonally amplified in OneTouch 2 System. DNA sequencing was performed on the Ion Personal Genome Machine.

The variant analysis was performed using the workflow "AmpliSeq CFTR single sample" in Ion Reporter Software. The variant pathogenicity was referred according to referenced database: www.genet.sickkids.on.ce [7]; cftr2.org/mutations_history_CFTR2_11March2019(1).xlsx [8]; varsom.com [24]; www.cftr.iurc.mont.inserm.fr [25]; www. ncbi.nlm.nih.gov/clinvar/ [26, 27].

\section{Results \\ CF screening}

Of the 1279 screened patients for CFTR, 71 (5.6\%) were diagnosed as a carrier of one CFTR mutation, 1 patient that was asymptomatic for $\mathrm{CF}$ was homozygous for D1270N, 1 patient was heterozygote compound (G542X; F1052V, asymptomatic patient), 1 patient was a carrier of F508del/N-TG12;5 T, 1 patient was a carrier of F1052V/N-TG12;5 T and 5 patients were carriers of pathogenic complex alleles. In total, 80 patients were diagnosed as carriers of at least one mutated CFTR gene (6.3\% or $1 / 16), 60$ males (5.7\% or $1 / 17.6)$ and 20 females (8.9\% or $1 / 11.2)$. Ten infertile couples discovered to be at risk of CF transmission during this screening.

Forty-four patients were carriers of the genomic variant TG12;5 T without CFTR mutation and 7 of benign complex allele. Fifty-four patients carried variants of uncertain significance (VUS): 24 undefined VUS, 4 VUS1, 2 VUS2, 8 VUS3 and 6 VUS4.

The theoretical risk of having an affected child with CF was calculated as 1 couple out of 256 of our Sicilian infertile couples $(1 / 256=1 / 16 \times 1 / 16)$.

Details of CFTR genotypes are reported in Table 1.

\section{Discussion}

Of the 1279 infertile patients tested in our laboratory for the screening of all CF mutations through NGS, 80 (6.3\%) were at risk of the transmission of a mutated CFTR gene. One infertile Sicilian patient out of 16 was diagnosed as a carrier of one mutated CFTR gene and it was calculated that 1 couple in 256 was at risk of $\mathrm{CF}$ transmission. The carrier frequency $(1 / 16)$ is 0.6 times more than expected for the Caucasian population which is estimated at 1 on 25 [1].

Twenty-four CFTR mutations were observed. In Sicily F508del was observed in 30.0\% (24/80) of CFTR mutations while it can reach up to $44.8 \%$ of CF causes in the rest of Italy [28]. The high genetic heterogeneity on the island of Sicily was previously demonstrated for HBB gene [29]. The high allele heterogeneity is explained by the multiple invasions during the centuries especially from Northern populations.

Different commercial kits for first level analysis [30] and NGS-assay screen for a large panel of mutations [31] but none of them test overall CFTR mutations found here. Respectively 12 and 6 of the mutations found in the present work would not have been detected with the strategies described elsewhere [30, 31]. 
Table 1 CFTR Genotype of the tested eastern Sicilian infertile population

\begin{tabular}{|c|c|c|c|c|c|}
\hline & CFTR Genotype & Male patient & Female patient & Total & References \\
\hline \multirow[t]{24}{*}{ Heterozygous for pathogenic mutation } & $\mathrm{D} 110 \mathrm{H} / \mathrm{N}$ & 0 & 1 & 1 & {$[7,8,24-26]$} \\
\hline & M952I/N & 2 & 1 & 3 & {$[7,25]$} \\
\hline & $R 74 W / \mathrm{N}$ & 3 & 2 & 5 & {$[7,8,24-26]$} \\
\hline & S945L/N & 1 & 0 & 1 & {$[7,8,24-26]$} \\
\hline & D1270N/ N & 2 & 0 & 2 & {$[7,8,24-26]$} \\
\hline & D110E/N & 1 & 1 & 2 & {$[7,8,24-26]$} \\
\hline & G1244E/N & 0 & 1 & 1 & {$[7,8,24-26]$} \\
\hline & $c .2490+2 T>C / N$ & 3 & 1 & 4 & {$[7,26]$} \\
\hline & $L 206 W / N$ & 1 & 0 & 1 & {$[7,8,24-26]$} \\
\hline & G1069R/N & 3 & 0 & 3 & {$[7,8,24-26]$} \\
\hline & $F 1052 \mathrm{~V} / \mathrm{N}$ & 5 & 3 & 8 & {$[7,8,24-26]$} \\
\hline & $621+3 A>G / N$ & 1 & 0 & 1 & {$[7,25,26]$} \\
\hline & $P 5 L / \mathrm{N}$ & 0 & 1 & 1 & {$[7,8,24-26]$} \\
\hline & $R 334 Q / \mathrm{N}$ & 1 & 0 & 1 & {$[7,8,24-26]$} \\
\hline & $3659 \mathrm{delC} / \mathrm{N}$ & 1 & 0 & 1 & {$[7,8,24-26]$} \\
\hline & $R 553 X / \mathrm{N}$ & 2 & 0 & 2 & {$[7,8,24-26]$} \\
\hline & F508del/N & 16 & 6 & 22 & {$[7,8,24-26]$} \\
\hline & $\mathrm{D} 1152 \mathrm{H} / \mathrm{N}$ & 1 & 0 & 1 & {$[7,8,24-26]$} \\
\hline & $W 1282 X / N$ & 2 & 0 & 2 & {$[7,8,24-26]$} \\
\hline & $N 1303 K / \mathrm{N}$ & 2 & 1 & 3 & {$[7,8,24-26]$} \\
\hline & $G 542 X / \mathrm{N}$ & 3 & 1 & 4 & {$[7,8,24-26]$} \\
\hline & $2183 A A \rightarrow G / N$ & 1 & 0 & 1 & {$[7,8,24-26]$} \\
\hline & CFTRdele22,23/N & 1 & 0 & 1 & {$[7,8,24-26]$} \\
\hline & Total & 52 & 19 & 71 & \\
\hline $\mathrm{HM}$ & D1270N/D1270N & 1 & 0 & 1 & {$[7,8,24-26]$} \\
\hline & Total & 1 & 0 & 1 & \\
\hline $\mathrm{HE}$ & G542X/F1052V & 1 & 0 & 1 & {$[7,8,24-26]$} \\
\hline & Total & 1 & 0 & 1 & \\
\hline Mutation/ polyT-polyTG & F508del/N-TG12; 5T & 1 & 0 & 1 & {$[7,8,24-26]$} \\
\hline & $F 1052 \mathrm{~V} / \mathrm{N}-\mathrm{TG} 12 ; 5 \mathrm{~T}$ & 1 & 0 & 1 & {$[7,8,24-26]$} \\
\hline & Total & 2 & 0 & 2 & \\
\hline Pathogenic CA & $R 74 W ; D 1270 N ; V 201 M / N$ & 1 & 1 & 2 & {$[7,8,24-26]$} \\
\hline & F508del; A238V/N & 1 & 0 & 1 & {$[7,8,24-26]$} \\
\hline & $D 1270 N ; R 74 W / \mathrm{N}$ & 2 & 0 & 2 & {$[7,8,24-26]$} \\
\hline & Total & 4 & 1 & 5 & \\
\hline polyT-polyTG & TG12; $5 \mathrm{~T}$ & 48 & 6 & 54 & {$[7,8,24-26]$} \\
\hline & Total & 48 & 6 & 54 & \\
\hline Non-Pathogenic CA & R75Q;P1290P;4251G/A/N & 1 & 0 & 1 & {$[7,8,24-26]$} \\
\hline & $\mathrm{G} 576 \mathrm{~A} ; \mathrm{R} 668 \mathrm{C} / \mathrm{N}$ & 6 & 0 & 6 & {$[7,8,24-26]$} \\
\hline & Total & 7 & 0 & 7 & \\
\hline vUS & $\mathrm{T} 582 \mathrm{~S} / \mathrm{N}$ & 1 & 1 & 2 & [7] \\
\hline & Y1073C/N & 1 & 0 & 1 & {$[7]$} \\
\hline & $\mathrm{T} 760 \mathrm{M} / \mathrm{N}$ & 1 & 0 & 1 & {$[7]$} \\
\hline & E528K/N & 1 & 0 & 1 & {$[7]$} \\
\hline
\end{tabular}


Table 1 CFTR Genotype of the tested eastern Sicilian infertile population (Continued)

\begin{tabular}{|c|c|c|c|c|c|}
\hline \multicolumn{2}{|c|}{ CFTR Genotype } & \multirow{2}{*}{$\frac{\text { Male patient }}{1}$} & \multirow{2}{*}{$\begin{array}{l}\text { Female patient } \\
0\end{array}$} & \multirow{2}{*}{$\frac{\text { Total }}{1}$} & \multirow{2}{*}{$\begin{array}{l}\text { References } \\
{[7]}\end{array}$} \\
\hline & Y1092C/N & & & & \\
\hline & $\mathrm{D} 1445 \mathrm{~N} / \mathrm{N}$ & 3 & 0 & 3 & {$[24,25]$} \\
\hline & c. $1633 \mathrm{G}>\mathrm{A} / \mathrm{N}$ & 1 & 0 & 1 & [24] \\
\hline & $\mathrm{S} 18 \mathrm{G} / \mathrm{N}$ & 2 & 0 & 2 & {$[24,25]$} \\
\hline & $\mathrm{C} .26 \mathrm{C}>\mathrm{T} / \mathrm{N}$ & 2 & 0 & 2 & {$[24,25]$} \\
\hline & L223F/N & 1 & 0 & 1 & [24] \\
\hline & c. $1806 C>A / N$ & 1 & 0 & 1 & [24] \\
\hline & c. $3710 \mathrm{G}>\mathrm{A} / \mathrm{N}$ & 1 & 0 & 1 & {$[25,26]$} \\
\hline & c.5282delA/N & 2 & 0 & 2 & [24] \\
\hline & c. $622-116 \mathrm{~A}>\mathrm{G} / \mathrm{N}$ & 1 & 0 & 1 & [24] \\
\hline & E528K & 1 & 0 & 1 & {$[7,26]$} \\
\hline & Y84H/N & 1 & 0 & 1 & {$[7,26]$} \\
\hline & G1130A/N & 1 & 0 & 1 & {$[7,26]$} \\
\hline \multirow[t]{3}{*}{ VUS 1} & $712-92 \mathrm{~T}>\mathrm{A} / \mathrm{N}$ & 1 & 0 & 1 & {$[24,25]$} \\
\hline & $1898+73 \mathrm{~T}>\mathrm{G} / \mathrm{N}$ & 2 & 1 & 3 & {$[24,25]$} \\
\hline & R74Q/N & 0 & 1 & 1 & {$[24,25]$} \\
\hline VUS 2 & $\mathrm{~S} 42 \mathrm{~F} / \mathrm{N}$ & 1 & 1 & 2 & {$[24,25]$} \\
\hline \multirow[t]{4}{*}{ VUS 3} & M348K/N & 4 & 0 & 4 & {$[24,25]$} \\
\hline & $\mathrm{K} 68 \mathrm{E} / \mathrm{N}$ & 1 & 0 & 1 & {$[24,25]$} \\
\hline & A959V/N & 1 & 1 & 2 & {$[24,25]$} \\
\hline & D192G/N & 1 & 0 & 1 & {$[24,25]$} \\
\hline \multirow[t]{7}{*}{ VUS 4} & c. $1762 \mathrm{G}>\mathrm{A} / \mathrm{N}$ & 0 & 1 & 1 & {$[24,25]$} \\
\hline & Y301C/N & 1 & 0 & 1 & {$[24,25]$} \\
\hline & V201M/N & 2 & 0 & 2 & {$[24,25]$} \\
\hline & $\mathrm{E} 1409 \mathrm{~K} / \mathrm{N}$ & 0 & 1 & 1 & {$[24,25]$} \\
\hline & L137P/N & 1 & 0 & 1 & {$[24,25]$} \\
\hline & c. $1495 \mathrm{C}>\mathrm{T} / \mathrm{N}$ & 1 & 0 & 1 & {$[24,25]$} \\
\hline & Total & 38 & 6 & 44 & \\
\hline
\end{tabular}

CA: complex allele; HE: heterozygous compound; HM: homozygous; $\mathrm{N}$ : wild-type allele; VUS: variant of uncertain significance *: classification as VUS 1 to 4 has not been determined yet according to The Human Genomics Community (24) and CFTR-France Database (25). Red ink: pathogenic CFTR mutation

Nota bene: the variant pathogenicity was referred according to referenced database: www.genet.sickkids.on.ce [7]; cftr2.org/mutations_historyCFTR2_11March201 9(1).xlsx [8]; varsom.com [24]; www.cftr.iurc.mont.inserm.fr [25]; www.ncbi.nlm.nih.gov/clinvar/ [26]

When a commercial test is applied, it is usually performed on both members of the couple in order to minimize the residual risk of being a couple at risk of CF transmission. In Italy, the Society of Human Genetics recommends performing the first level CFTR screening only if one partner was identified as a carrier [32]. In our present strategy the entire CFTR gene is sequenced in only one member of all couples and extended to the second member only if the first member is diagnosed as a carrier. Consequently, the residual risk of being a carrier is drastically decreased and depends only on the discovery of unknown CFTR mutations.
In scientific literature, data are still missing on the clinical signification of variants called VUS [24]. In these cases, the genetic counseling for reproductive choice and genetic selection with prenatal diagnostic or PGT becomes difficult. Genomic variants such as F508C were classified as mutations causing at first [25], then have been subsequently downgraded as benign [8]. Other genomic variants such as T582S are only reported as a mutation on the Cystic Fibrosis Mutation Database and as suspicious VUS according to The Human Genomics Community [24].

CF remains among the widespread diseases tested especially at preimplantation stage [33-35]. In 2016, an 
international consensus was found for the best practice for PGT of CF [36]. We developed and clinically applied a universal strategy for PGT based on NGS to diagnose CF mutations found in Sicily [23].

\section{Conclusion}

$\mathrm{CF}$ is the most widespread autosomal recessive disease present in the Caucasian population with a very large allele variability as 383 mutations have been recently listed and many genomic variations have clinical consequences to ascertain. In the present work, we showed how the longitudinal screening of the entire CFTR gene is determinant for the detection of all the mutations within a specific population. In our tested Sicilian infertile population, the theorical risk of being a carrier was $1 / 16$, that is 0.6 times more than the 1/25 Caucasian reference. Consequently, it was calculated that one couple out of 256 was at risk of having an affected child. At least 24 CFTR gene mutations are present in the Sicilian population.

\section{Abbreviations \\ CBAVD: Congenital Bilateral Absence of Vas Deferens; CF: Cystic fibrosis; CFTR: Cystic Fibrosis Transmembrane Regulator; IGV: Interactive Genomic Viewer; NGS: Next-Generation Sequencing; PGT: Preimplantation Genetic Testing; VUS: Variances of Uncertain Significance}

\section{Acknowledgments}

Not applicable

\section{Authors' contribution}

SC: wrote the manuscript and contributed to NGS analysis; MS: contributed to manuscript writing, performed NGS analysis; DL: contributed to manuscript writing; EM, AL, CC, MF and EV enrolled patients and performed clinical investigations, AG enrolled patients, performed clinical investigations and contributed to manuscript writing. All authors read and approved the final manuscript.

\section{Funding}

Not applicable

\section{Availability of data and materials}

The data of the manuscript are available in: https://apps.thermofisher.com/ apps/spa/\#/dashboard; Username: hera.sharedata@gmail.com; password: sharedata2020.

\section{Ethics approval and consent to participate}

Each part of the protocol has been approved by the Institutional Review Board Unità di Medicina della Riproduzione - Centro HERA. The patients signed informed consent forms on all procedures prior application.

\section{Consent for publication}

Not applicable

\section{Competing interests}

The authors declare that they have no competing interests.

\section{Author details}

'Unità di Medicina della Riproduzione - Centro HERA, via Barriera del Bosco n. 51/53, 95030 Catania, Sant'Agata Li Battiati, Italy. ${ }^{2}$ Unit of Gynecology and Obstetric - Department of general surgery and medical surgical specialties, University of Catania, Catania, Italy.
Received: 24 October 2019 Accepted: 21 January 2020

Published online: 01 May 2020

\section{References}

1. Strom CM, Crossley B, Buller-Buerkle A, Jarvis M, Quan F, Peng M, Muralidharan K, Pratt V, Redman JB, Sun W. Cystic fibrosis testing 8 years on: lessons learned from carrier screening and sequencing analysis. Genet Med. 2011:2:166-72

2. Southern KW, Munck A, Pollitt R, Travert G, Zanolla L, Dankert-Roelse J, Castellani. A survey of newborn screening for cystic bibrosis in Europe. $J$ Cyst Fibros 2006; 6:57-65.

3. Riordan JR, Rommcns JM, Kerem B-S, Alon N, Rozmahel R, Grzelczak Z, Zielenski J, Lok S, Plavsic N, Chou J-L, et al. Identification of the cystic fibrosis gene: cloning and characterization of complementary DNA. Science. 1989;245:1066-73.

4. Rommens JM, lannuzzi MC, Kerem B, Drumm ML, Melmer G, Dean M, Rozmahel R, Cole JL, Kennedy D, Hidaka N. Identification of the cystic fibrosis gene: chromosome walking and jumping. Science. 1989;245(4922):1059-65.

5. Welsh MJ, Smith AE. Molecular mechanisms of CFTR chloride channel dysfunction in cystic fibrosis. Cell. 1993:73(7):1251-4

6. Gadsby DC, Vergani P, Csanady L. The ABC protein turned chloride channel whose failure causes cystic fibrosis. Nature. 2006:440:477-83.

7. Cystic Fibrosis Mutation Database. www.genet.sickkids.on.ca/cftr

8. Clinical and Functional Translation of CFTR. cftr2.org/mutations_history CFTR2_11March2019(1).xlsx.

9. Bombieri C, Claustres M, De Boeck K, Derichs N, Dodge J, Girodon E, Sermet I, Schwarz M, Tzetis M, Wilschanski M et al. Recommendations for the classification of diseases as CFTR-related disorders. Journal of Cystic Fibrosis. 2011; Jun 10 Suppl 2: S86-102. doi: https://doi.org/10.1016/S1569-1993(11)60014-3.

10. Hayslip CC, Hao E, Usala SJ. The cystic fibrosis transmembrane regulator gene is expressed in the human endocervix throughout the menstrual cycle. Fertil Steril. 1997;67:636-40.

11. Patrizio P, Salameh WA. Expression of the cystic fibrosis transmembrane conductance regulator (CFTR) mRNA in normal and pathological adult human epididymis. J Reprod Fertil Suppl. 1998:53:261-70.

12. Wong PY. CFTR gene and male infertility. Mol Hum Reprod. 1998;4:107-10.

13. Chillón M, Casals T, Mercier B, Bassas L, Lissens W, Silber S, Romey MC, RuizRomero J, Verlingue C, Claustres $\mathrm{M}$, et al. Mutations in the cystic fibrosis gene in patients with congenital absence of the vas deferens. N Engl J Med. 1995;332(22):1475-80

14. Radpour R, Gourabi H, Dizaj AV, Holzgreve W, Zhong XY. Genetic investigations of CFTR mutations in congenital absence of vas deferens, uterus, and vagina as a cause of infertility. J Androl. 2008; 29(5): 506-513. doi: https://doi.org/10.2164/jandrol.108.005074. Epub 2008 Jun 20.

15. Groman JD, Hefferon TW, Casals T, Bassas L, Estivill X, Des Georges M, Guittard C, Koudova M, Fallin MD, Nemeth K, et al. Variation in a repeat sequence determines whether a common variant of the cystic fibrosis transmembrane conductance regulator gene is pathogenic or benign. Am J Hum Genet. 2004;74(1):176-9 Epub 2003 Dec 18

16. Tamburino L, Guglielmino A, Venti E, Chamayou S. Molecular analysis of mutations and polymorphisms in the CFTR gene in male infertility. Reprod BioMed Online. 2008;17(1):26-35.

17. Berwouts S, Morris M, Girodon E, Shwartz M, Stuhrmann M, Dequeker E. Mutation nomenclature in practice: findings and recommnentations from the cystic fibrosis external quality assessment scheme. Human Mutat. 2011; Nov;32(11):197-203

18. Dequeker E, Stuhrmann M, Morris M, Casals T, Castelini C, Claustres M, Cuppens H, Des Georges M, Ferec C, Macek M, et al. Best practice guidelines for molecular genetic diagnosis of cystic fibrosis and CFTR-related disordersupdated European recommendations. Eur J Human Genet. 2009;17:51-65.

19. Bombieri C, Pignatti PF. Cystic fibrosis mutation testing in Italy. Genet Test. 2001:5:229-33

20. Rendine S, Calafell F, Cappello N, Gagliardini R, et al. Genetic history of cystic fibrosis mutations in Italy. I regional distribution. Ann Human Genet. 1997;61:411-24

21. Chamayou S, Sicali M, D'Apice MR, Rosatelli C, Coiana A, Covone E, Ferrari S, Mazza C, Savoldi G, Sobrino Rey B et al. Molecular analysis of mutations in the CFTR gene using Next Generation semiconductor sequencing platform. European Journal of Human Genetics. 2014; P14.51-S.

22. Trujilano D, Weiss MER, Köster J, Papachristos EB, Werber M, Kandaswamy KK, Marais A, Eichler S, Creed J, Baysal E, et al. Validation of a semiconductor 
next-generation sequencing assay for the clinical genetic screening of CFTR. Mol Genet Genom Med. 2015;3(5):396-403.

23. Chamayou S, Sicali M, Lombardo D, Alecci C, Ragolia C, Maglia E, Liprino A, Cardea C, Storaci G, Romano S, Guglielmino A. Universal strategy for preimplantation genetic testing for cystic fibrosis based on next generation sequencing. Journal of Assisted Reproduction and Genetics. 2019; In press.

24. The Human Genomics Community. varsome.com.

25. CFTR-France Database. cftr.iurc.montp.inserm.fr/cftr/.

26. ClinVar. www.ncbi.nlm.nih.gov/clinvar/.

27. Richards S, Aziz N, Bale S, Bick D, Das S, GAStier-Foster J. Standards and guidelines for the interpretation of sequence variants: a joint consensus recommendation of the American college of medical genetics and genomic and the association for molecular pathology. Genet Med. 2015; 17(5):405-24.

28. Giordani B, Mamato A, Majo F, Ferrari G, Quattrucci S, Minicucci L, Padoan R, Floridia G, Puppo Fornaro G et al. Italian Cystic Fibrosis Registry Report. Epidemiologia e Prevenzione. 2018; 42(S1)

29. Giambona A, Lo Gioco P, Marino M, Abate I, Di Marzo R, Renda M, Di Trapani F, Messana F, Siciliano S, Rigano P. The great heterogeneity of thalassemia molecular defects in Sicily. Hum Genet. 1995;95(5):526-30.

30. Molinario R, Palumbo S, Rocchetti S, Rizza R, Zuppi C, Capoluongo E. Diagnosi molecolare di primo livello nella fibrosi cistica: confronto tra tre metodiche commerciali. Biochimica Clinica. 2015:39:193-9.

31. Lucarelli M, Porcaro L, Biffignandi A, Costantino L, Gioannone V, Alberti L, Bruno SM, Corbetta C, Torresani E, Colombo C, Seia M. A new targeted CFTR mutation planed based on next-generation Sequency technology. J Mol Diagnosics. 2017;19(5):788-800.

32. Società Italiana di Genetica Umana - Tavolo di consenso: Test genetici nel percorso della procreazione medicalmente assistita (PMA). 2016; www.sigu.net.

33. Keymolen K, Goosens V, De Rycke M, Sermon K, Boelaert K, Bonduelle M, Van Steirteghem A, Liebaers I. Clinical outcome of preimplantation genetic diagnosis for cystic fibrosis: the Brussels'experience. Eur J Hum Genet. 2007;15:752-8.

34. Girardet A, Ishmukhametova A, Willems M, Coubes C, Hammamah S, Anahory T, Georges MD, Claustres M. Preimplantation genetic diagnosis for cystic fibrosis: the Montpellier center's 10-year experience. Clin Genet. 2015;87:124-32.

35. De Rycke M, Belva M, Goosens V, Moutou C, SenGupta SB, TraegerSynodinos J, Coonen E. ESHRE PGD consortium data collection XIII: cycles from January to December 2010 with pregnancy follow-up to October 2011. Hum Reprod. 2015;30(8):1763-89.

36. Girardet A, Viart V, Plaza S, Daina G, De Rucke M, Des Gearges M, Fiorentino F, Harton G, Ishmukhametova A, Navarro J, et al. The improvement of the best practice guidelines for preimplantation genetic diagnosis of cystic fibrosis: toward an international consensus. Eur J Hum Genet. 2016;24:469-78.

\section{Publisher's Note}

Springer Nature remains neutral with regard to jurisdictional claims in published maps and institutional affiliations.

Ready to submit your research? Choose BMC and benefit from:

- fast, convenient online submission

- thorough peer review by experienced researchers in your field

- rapid publication on acceptance

- support for research data, including large and complex data types

- gold Open Access which fosters wider collaboration and increased citations

- maximum visibility for your research: over $100 \mathrm{M}$ website views per year

At $\mathrm{BMC}$, research is always in progress.

Learn more biomedcentral.com/submissions 